\title{
PERANAN KEPELATIHAN OLAHRAGA SEBAGAI PENDIDIK, PELATIH DAN PEMBINA OLAHRAGA DI SEKOLAH
}

\author{
Boy Indrayana \\ Fakultas Ilmu Keolahragaan Universitas Jambi \\ Email : Boy_indrayana@unja.ac.id
}

\begin{abstract}
School education plays important roles in laying the foundations of abilities, skills, and morale for creating better human resources. School is a potential place to prepare athletes starting from early age. Physical education subject can be an effective tool to create potential athletes to advance national sport achievements. Sport coaches, as professionals, apart from their role as educators and curriculum implementers, must be able to run extracurricular activities as coach and mentors at school.

This articles aims to discuss sport coaching at schools, the application of sport coaching, physical education curriculum, school sport achievement education, and development of prospective athletes since early age.
\end{abstract}

Keywords: sport coaching, coaching for sport achievement, school.

\begin{abstract}
ABSTRAK
Pendidikan di sekolah sangat berperan dalam meletakkan dasar-dasar kemampuan, keterampilan, dan moral untuk mencapai peningkatan sumber daya manusia. Sekolah merupakan tempat yang potensial untuk mempersiapkan atlet dari usia dini. Pendidikan jasmani dapat menjadi alat pendidikan yang dapat menghasilkan atlet berpotensi dalam menunjuang prestasi olahraga nasional. Kepelatihan olahraga, sebagai tenaga professional, di samping menjadi tenaga pendidik dan pelaku kurikuler mampu menyelengggarakan program ekstrakulikuler sebagai peltaih dan Pembina olahraga di sekolah.

Artikel ini membahas tentang kepelatihan olahraga di sekolah, aplikasi kepelatihan olahraga, kurikukulum pendidikan jasmani, pendidikan prestasi olahraga di sekolah, pengembangan calon atlet dari usia dini.
\end{abstract}

Kata kunci: kepelatihan olahraga, pembinaan prestasi, sekolah.

\section{PENDAHULUAN}

Zaman kesenjangan mendatang merupakan masa penuh persaingan dalam segala bidang kehidupan. Suatu bangsa yang ingin bertahan dan berjalan dengan baik harus menyiapkan dan mewakili sumber daya manusia yang lebih baik. Sumber daya manusia yang dimiliki oleh setiap bangsa harus memiliki kemampuan intelektual yang tinggi, mentalyang tangguh dan perlu pula ditopang oleh kebugaran dan kemampuan fisik yang baik.

Kebugaran dan kemampuan fisik yang baik akan dapat menyumbang tingkat pendapatan perorangan dan produktifitas negara dibandingkan dengan warga yang memiliki tingkat kebugaran dan kemampuan fisik yang lebih rendah. Aktivitas berolahraga merupakan salah satu cara yang dipilih untuk 
meningkatkan dan memmertahankan kebugaran dan kemampuan fisik seseoarang. Kegiatan olahraga pada saat ini berhubungan dengan prestasi. Prestasi olahraga menyangkut pula martabat suatu negara. Prestasi yang dicapai olahragawan dari berbagai even dunia didominasi oleh olahragawan dari negara besar dan maju, yang memiliki pendapatan perkapita lebih baik, di mana kegiatan berolahraga telah menjadi bagian dari kehidupan masyarakat. Pembinaan prestasi telah dilakukan melalui pendekatan ilmiah, penerapan teknologi secara terencana terhadap calon atlet.

Penyiapan calon atlet dilakukan sejak dini dan dimulai sejak anak-anak. Anak dan remaja merupakan calon atlet, sekolah merupakan salah satu tempat anak dan remaja dikumpulkan secara sengaja untuk memperoleh pengetahuan dan keterampilan. Dari sudut pembibitan dan pembinaan calom olahragawan, sekolah merupakan "ladang" dan sumber yang berpotensi yang relatif cukup mudah dicapai dan dikelola. Melalui penanganan yang tepat, sesuai dengan tingkat dan jenjang sekolah, siswa dapat dipersiapkan sebagai atlet yang diharapkan.

\section{KAJIAN PUSTAKA Kepelatihan Olahraga di Sekolah}

Sekolah sebagai lembaga pendidikan, ditopang oleh sejumlah guru sebagai sumber daya manusia yang menangani peserta didik menuju kedewasaannya. Pendidikan di sekolah sangat berperan dalam meletakkan dasar-dasar kemampuan, keterampilan, dan moral untuk mencapai peningkatan sumber daya manusia. Pendidikan dilaksanakan guru melalui proses pembelajaran berbagai mata ajar yang dianggap relevan dan telah diatur di dalam kurikulum sesuai dengan jenjang dan jenis sekolah.

Kepelatihan Olahraga adalah suatu pendidikan yang dikemas di mana sasaran dan tujuannya untuk menciptakan para pelatih yang nantinya akan menghasilkan atlet-atlet yang berprestasi sesuai dengan harapan dan standar penerapan pendidikan atau pelatihan yang mengarah pada pembinaan prestasi jangka panjang. Dengan kata lain, Kepelatihan olahraga merupakan proses pelatihan melalui gerakan insani yang dilakukan dengan gerakan tubuh berupa: aktivitas jasmani, permainan, atau melalui cabang-cabang olahraga yang diarahkan untuk mencapai tujuan prestasi. Kepelatihan olahraga berperan sebagai sarana pembinaan dan pengembangan individu maupun kelompok dalam menunjang pertumbuhan dan perkembangan jasmani, kesehatan, mental, sosial, serta emosional yang serasi, seimbang, dan selaras. Sumbangan kegiatan fisik terhadap anak dilukiskan oleh Gabbard dkk. sebagai berikut:

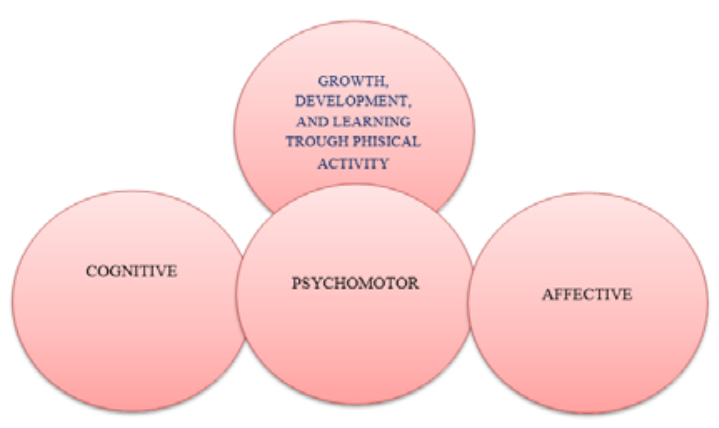




\section{Penerapan Kepelatihan Olahraga}

Olahraga merupakan penampakan aktivitas fisik (jasmani) yang melibatkan proses internal diri sebagai individu manusia. Dimaksudkan dengan internal diri di sini adalah keterlibatan rohani sebagai suatu kesatuan dari manusia yang terdiri dari jasmani dan rohani. Jadi, pada dasarnya aktivitas olahraga adalah aktivitas jasmani dan rohani. Dengan demikian, dapat dikatakan bahwa olahraga merupakan aktivitas dalam upaya membentuk dan mengembangkan raga (jasmani-rohani) menuju optimalisasi potensi diri.

Manusia ditinjau dari aspek jasmani terdiri dari anggota tubuh dan organ-organ (fisiologi). Sedangkan dari aspek rohani menyangkut pikir dan mental kejiwaan (psikologi-kerohanian). Pemahaman tentang konsep manusia ini akan menjadi landasan dalam melakukan aktivitas olahraga, baik yang bertujuan untuk kebugaran jasmani terlebih lagi untuk tujuan olahraga prestasi. Oleh karena itu, berbagai kajian seputar manusia akan melandasi pembahasan dan pengkajian secara ilmiah tentang keolahragaan, misalnya seperti dikemukanan oleh Pate dkk (1984) bahwa terdapat 3 disiplin keilmuan yang mendasai pelatihan olahraga yaitu: (1) psikologi olahraga (2) biomekanika, (3) fisologi Olahraga. Selanjutnya, diuraikan Bompa (1990) bahwa ilmu yang mendukung teori dan metode pelatihan olahraga adalah: (1) anatomi, (2) fisiologi, (3) biomekanika, (4) statistik, (5) tes dan pengukuran, (6) kedokteran olahraga, (7) psikologi, (8) pembelajaran gerak, (9) pedagogi, (10) nutrisi, (11) sejarah, (12) sosiologi.

Optimalisais potensi diri yang paling utama dalam beolahraga adalah untuk memperoleh derajat kesehatan yang sebaikbaiknya dan seimbang antara jasmani dan rohani. Berlandandaskan sehat ini akan lebih mudah mengembangkan minat dan bakat olahraga ke arah prestasi yang tinggi. Makin tinggi tuntutan prestasi maka makin tinggi pula tuntutan sehat. Karena tidak mungkin berprestasi tanpa kesehatan yang prima. Dengan demikian, dapat dipahami bahwa prestasi olahraga merupakan produk berikutnya dari sehat dalam upaya optimalisasi potensi diri manusia. Melalui pemahaman ini dapat dikatakan bahwa aktivitas olahraga merupakan kegiatan yang dapat membentuk watak atau kepribadian bangsa.

\section{Olahraga dalam Mengoptimalkan Potensi Jasmani}

Potensi jasmani dimaksud dalam tulisan ini adalah menyangkut pertumbuhan dan perkembangan kemampuan jasmani sesuai dengan fungsi alamiahnya, yakni ditinjau dari aspek jasmani itu sendiri baik struktur tubuh dan geraknya maupun fungsi oragannya (anatomi-biomekanika-fisiologi). Tumbuh dan kembang harus seimbang dan selaras untuk mendapatkan jasmani yang baik. Pertumbuhan lebih dititik beratkan pada 
fungsi gerak dan struktur dan organ tubuh yang semakin baik dan matang. Oleh karena itu, pertumbuhan terjadi terutama tergantung pada hormon pertumbuhan yakni sampai fase remaja (struktur) sedang perkembangan terus sampai dewasa (kematangan struktur dan fungsi organ tubuh).

Potensi jasmani dimaksudkan dalam kaitannya dengan olahraga adalah optimalnya kerja struktur (anggota tubuh) dan fungsi organ tubuh. Semua anggota tubuh berkemampuan melakukan gerakan secara optimal sesuai dengan kemungkinan geraknya (pronsip anatomi-biomekanika). Untuk mencapai semua itu, maka gerak dasar tubuh harus dilakukan sejak dini secara terus menerus dengan baik dan benar. Menurut penulis, inilah hakekat dari multilateral sebagai fundasinya pembinaan olahraga prestasi yang dalam program jangka panjang memerlukan waktu pembinaan sampai 4 tahun sebelum mamasuki tahapan pembinaan (3 tahun) dan pemantapan prestasi (3 tahun) sampai pada prestasi puncak (usia emas).

Sedemikian besarnya peran multilateral dalam pembinaan olahraga prestasi namun, implementasinya di lapangan justru belum dipahami secara benar sehingga terkesan diabaikan. Kepelatihan terlalu cepat memasuki tahapan pembinaan spesialisasi cabang olahraga, sementara pondasinya belum terbentuk dengan baik dan benar. Akibatnya, dasar gerak dan gerak dasar cabang olahraga belum dikuasai secara benar sehingga prestasi sulit ditingkatkan. Ada beberapa kemungkinan yang menyebabkan tahapan pembinaan multilateral tidak dilaksanakan secara benar, yaitu antara lain kurangnnya pengetahuan secara teori maupun praktik tentang multilateral dan perannya dalam olahraga prestasi dan sikap tidak sabaran akan cepat menghasilkan prestasi, dua hal ini nampaknya punya andil besar dalam kemajuan olahraga prestasi di Indonesia dalam implementasi kepelatihan di lapangan karena menyangkut pondasi prestasi.

Multilateral pada hakekatnya adalah gerak dasar tubuh yang merupakan dasar gerakan dari cabang olahraga dan oleh karena itu, maka multilateral harus dilakukan sedini mungkin (sejak usia dini) dan bahkan tetap masih dilakukan meskipun atlet sudah berada pada tahapan puncak prestasi.

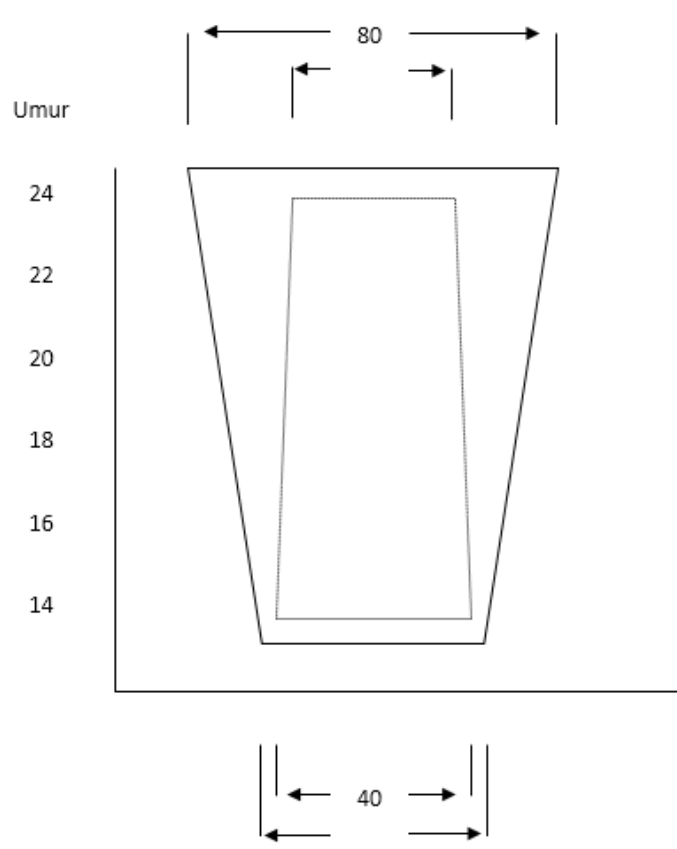

Gambar 1. Rasio antara pengembangan multilateral dengan pembinaan spesialisasi. (dikutip dari Bompa, 1990:33) 
Dari gambar 1 terlihat rasio antara pengembangan multilateral dan pembinaan spesialisasi Pretasi multilateral lebih tinggi pada usia dini dan semakin kurang pembinaanya pada usia puncak prestasi. Sementara spesialisasi semakin besar porsi pembinaannya menuju usia puncak prestasi. Adapun ditinjau dari fase pelatihan, maka multilateral menjadi pondasi dari speseialisasi dan kenerja puncak seperti terlihat pada gambar 2.

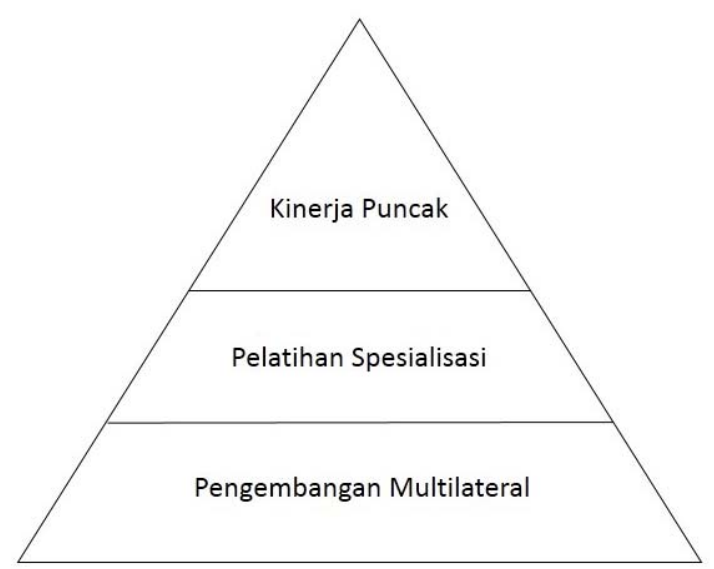

Gambar 2. Fase utama pelatihan (Bompa, 1990:31)

Gambar 2 menujukkan bahwa fase pengembangan multilateral merupakan dasar atau pondasi dari proses pembinaan olahraga prestasi. Artinya, tanpa multilateral yang terbina dengan baik dan benar tidak akan dapat pengembangan dan membentuk kebutuhan karakteristik spesialisasi cabang olahraga bersangkutan secara sempurna untuk menuju kinerja puncak prestasi.

Uraian di atas telah menunjukkan kepada kita bahwa olahraga yang dilakukan dengan benar akan dapat membentuk tubuh dengan baik dan berungsi secara optimal selaras dengan pertumbuhan dan perkembangan tubuh. Oleh karena itu, berolahraga harus dilakukan secara terus menerus agar tubuh dapat berfungsi secara optimal dan tidak mengalami penurunan kemampuan yang seharusnya bisa dicegah dengan aktivitas olahraga. Inilah hakekat olahraga, untuk kesehatan dan dari dasar sehat, ditingkatkan menuju pembinaan olahraga prestasi.

\section{Kurikulum Pendidikan Jasmani}

Kurikulum pendidikan jasmani yang berlaku sekarang di setiap jenjang dan jenis sekolah merupakan hasil pemikiran dan kerja tim kurikulum beserta para ahli pendidikan dan pendidikan jasmani dengan mempertimbangkan faktor-faktor; pertumbuhan dan perkembangan anak, kemampuan guru, keterbatasan sasaran dan prasarana, alokasi waktu yang tersedia, keterlaksanaan, keluwesan, serta pengembangan cabang-cabang olahraga yang berpotensi. Kegiatan yang diajarkan oleh guru meliputi: kegiatan pokok dan kegiatan pilihan. Kegiatan pokok terdiri dari: senam, atletik, dan permainan. Sedangkan, kegiatan pilihan terdiri atas: renang dan cabang-cabang olahraga yang berpotensial dan berkembang di daerah (diberikan kepada setiap daerah atau sekolah untuk menetapkan).

Guna mencapai tujuan pendidikan jasmani, secara keseluruan program pengajaran menurut pertimbangan ;

- Urutkan pelaksanaan dari yang mudah ke sukar, dari yang sedang ke kompleks, 
dari dekat ke jauh dan dari rendah ke tinggi.

- Variasi setiap pelaksanaan, seperti majumundur, kiri-kanan, serong, pelan-cepat dan lebih cepat.

- Bentuk pelaksanan dengan mengacu kepada perorangan, berpasang-pasangan, beregu, kelompok, dan klasikal.

- Sifat pelaksanaan, dilakukan dengan bebas, terikat, penugasan, mencipta, aktif, kreatif.

- Cara pelaksanaan dengan melalui latihan, meniru, permainan, perlombaan, pertandingan dan tes.

Sejarah pembelajaran pendidikan jasmani selama ini memperlihatkan, bahwa terdapat dua istilah yang saling tumpang tindih, sukar untuk dipisahkan, yaitu antara pendidikan jasmani dan pendidikan olahraga. Di satu sisi, pendidikan jasmani sebagai alat pendidik menekan pada pertumbuhan dan perkembangan gerak, sedangkan di sisi lain cabang olahraga yang dipergunakan sebagai alat mengarahkan kepada keterampilan khusus kepada prestasi olahraga.

Prestasi yang keliru dalam penerapan mata ajar pendidikan jasmani dapat menimbulkan miskonsepsi terhadap pembinaan usia dini. Pembinaan usia dini yang dipahami oleh guru pendidkan jasmani sebagai memperkenalkan dan untuk menguasai suatu cabang olahraga akan menekankan pada penguasaan keterampilan kusus dan prestasi. Hal ini membukakan kesempatan kepada guru berupa pelaksanaan pembelajaran dan perlakuan kepada siswa berbentuk istilah yang berlebihan tanpa mempertimbangkan : Usia, dan perbedaan pertumbuhan, perkembangan serta kemampuan individu.

Prestsai sebagai penampilan khusus yang kompleks merupakan hasil dari penguasaan dan pengayaan serta penerapan gerakan dalam berbagai situasi dan kondisi akan lebih mudah diperoleh melalui tahapan perkembangan gerak. Hubungan pembinaan usia dini dengan prestasi melalui pendidikan jasmani dapat digambarkan sebagai pramida di bawah ini.

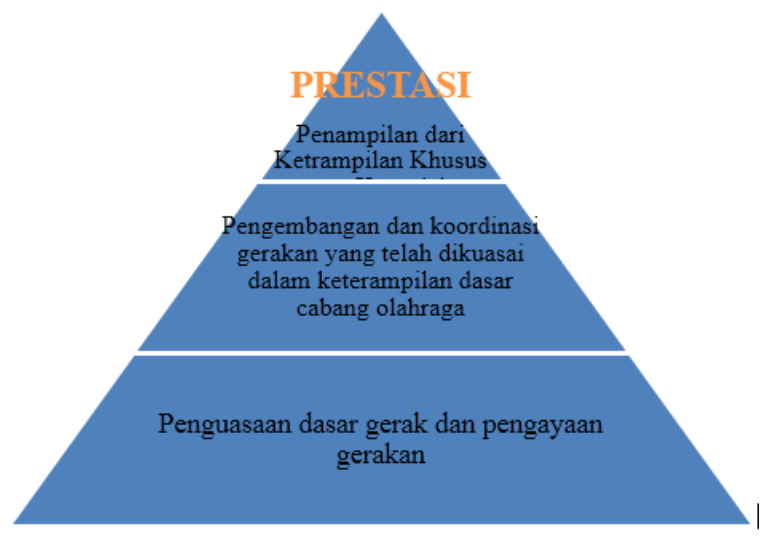

Keterampilan khusus akan lebih mudah dicapai apabila memiliki berbagai gerakan sebelumnya. Proses pencapaian keterampilan tidak memerlukan waktu yang lama. Sedangkan, bagi siswa yang telah kaya akan berbagai gerakan, pada tahap penguasaan teknik kecabangan sangat terbantu, dapat menguasai teknik permainan lebih cepat. Di samping itu telah memungkinkan untuk meningkatkan faktor pendukung lain dalam berprestasi. 
Mengingat keterbatas waktu berupa jumlah jam pertumbuhan secara formal sesuai dengan jadwal yang telah dipersiapkan oleh sekolah (program Ekstrakurikuler) untuk memenuhi tuntutan siswa yang ingin mengembangkan bakat dan kegemarannya tidak terturtup kemungkinan bagi sekolah, khususnya guru pendidikan jasmani, untuk menyelenggarakan gerakan ekstrakurikuler sehingga pembinaan dan pelatihan lebih efektif.

\section{Pembinaan Prestasi Olahraga di Sekolah}

Dengan melaksanakan ekstrakurikuler saja, sekolah dan guru pendidikna jasmani relatif sukar memiliki atlet berprestasi. Dengan keterbatasan kurikuler keterampilan khusus sulit untuk dibina. Ekstrakurikuler memiliki kelonggaran waktu dan aneka aktivitas dibandingkan dengan program kurikuler. Melalui program ekstrakurikuler, dapat disusun tahapan kegiatan dan perinsip latihan sesuai dengan kebutuhan. Seorang guru pendidikan jasmani akan lebih mengetahui dan memahami sehubungan dengan calon atletnya yang juga adalh siswa. Calon atlet yang mengikuti ekstrakurikuler datang dengan berbagai latar belakang dan kemampuan. Berdasarkan kemampuan yang dimiliki calon atlet dan untuk mencapai efektifitas latihan dapat dipedomani, bahwa calon atlet dapat disiapkan menjadi kelmpok tahap; pemula, menengah, dan lanjutan (Pate, dkk, 1984). Pada tingkat pemula, biasanya calon atlet berusaha keras untuk memahami teknik yang diperkenalkan, diterangkan, dan diperagakan ia akan berusaha berkonsentrasi untuk mengembangkan imajinasi dan perasaan gerak yang terpadu. Biasanya dilatih untuk menguasai satu bagian dari sekian banyak bagian suatu keterampilan dengan baik dan otomatis, selanjutnya mempelajari bagian lain yang akhirnya sesuai kepada menyatukan bagian demi bagian menjadi suatu gerakan terpadu. Umumnya kesalahan yang sering dilakukan adalah penampilan yang jauh dari yang diharapan. Umpan balik selama peroses latihan sangat diperlukan dalam bentuk sederhana dan mudah dimengerti.

Calon atlet tingkat menengah, telah memiliki kemampuan keterampilan tetapi belum begitu baik. Sangat diperlukan frekuensi pengulangan yang lebih, kegiatan latihan yang dominan oleh pencapaian dan pelaksanaan strategi latihan yang efektif. Diperlukan penguasaan keterampilan yang bervariasi. Pada tingkat ini calon atlet memerlukan dukungan dari semua pihak.

Tahap lanjutan, dituntut latihan untuk mengembangkan keterampilan secara konsisten dalam situasi sebenarnya dan beragam. Calon atlet telah memahami dengan keterampilannya sendiri bahkan telah dapat mengoreksi kesalahannya sendiri. Pembina dan pelatih diharapkan membantu seperlunya. Penekanan bagi calon atlet lanjut adalah disiplin diri dan latihan penuh. Tingkat penampilan lebih otomatis, cepat dan mulus. Perhatian pembinaan mulai dapat diarahkan kepada strategi dan masalah lain. 
Prestasi yang diperoleh seseorang didukung oleh berbagai faktor yang semuanya dilatih dan dibina sebelumnya secara berharap. Bompa, 1990, menggambar hubungan prestasi dengan tahapan pembinaan yang dilakukan sebagai piramida dibawah ini

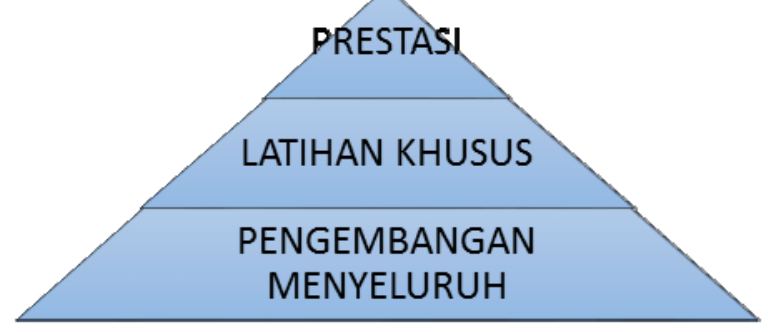

Pada tahap awal, seorang calon atlet sebaiknya memperoleh pembinaan latihan fisik secara menyeluruh, pengembangan menyeluruh dari kemampuan fisik yang sampai pada tahap terbaik akan sangat mendukung tahap latihan khusus dalam penguasaan teknik secara tuntas.

\section{Pengembangan Calon Atlet dari Usia Dini}

Pembinaan usia dini menuju penampilan yang terbaik pada saat mendatang dari satu sisi dianggap sebagai usaha memberikan latihan khusus cabang olahraga kepada anak sesegera. Pemberian latihan khusus kecabangan olahraga kepada anak dengan harapaan anak akan memiliki keterampilan dan penampilan yang lebih baiak. Pencapaian prestasi olahraga dianggap sulit dicapai karena jarak waktu pembinaan dan prestasi yang ditampilkan memerlukan waktu yang lama. Spesialisasi sejak usia dini merupakan pekerjaan yang kompleks, memerlukan pertimbangan yang matang. Usia dini memiliki karakteristik tersendiri.

Sebagai pembina usia dini masih mengarah pada penguasaan teknik kecabangan, teknik dan psikologis masih dapat di tolelir, tetapi pembinaan yang berhunbungan dengan kemampuan maksimal fisik perlu dipertimbangkan. Setiap cabnag olahraga memiliki tuntutan kemampuan fisik yang berbeda. Pemaksaan latihan guna meningkatkan kemampuan fisik terhadap usia dini tentu membawa akibat yang kurang baik bagi anak dalam menuju kedewasaannya.

Bompa (1994) dalam (Harsono, 2016 :65) mengidentifikasi sejumlah cabang olahraga dan pembinaan usia dini dalam umur pemula, spesialisasi, dan prestasi puncak seperti tabel di bawah ini.

\begin{tabular}{|c|l|c|c|c|}
\hline No & Cabang Olahraga & $\begin{array}{c}\text { Usia Pemulaan } \\
\text { Olahraga }\end{array}$ & $\begin{array}{c}\text { Usia } \\
\text { Sepesialisasi }\end{array}$ & $\begin{array}{c}\text { Usia Prestasi } \\
\text { Puncak }\end{array}$ \\
\hline 1 & Atletik & $10-12$ & $13-14$ & $18-23$ \\
\hline 2 & Bola Basket & $7-8$ & $10-12$ & $20-25$ \\
\hline 3 & Tinju & $13-14$ & $15-16$ & $20-25$ \\
\hline 4 & Balap Sepeda & $14-15$ & $16-17$ & $21-24$ \\
\hline 5 & Luncat indah & $6-7$ & $8-10$ & $18-22$ \\
\hline 6 & Skating/Sepatu Roda & & & \\
\hline 7 & Anggar & $8-9$ & $10-12$ & $20-25$ \\
\hline 8 & Senam (Putri) & $6-7$ & $10-11$ & $14-18$ \\
\hline & Senam (Putra) & $6-7$ & $12-14$ & $18-24$ \\
\hline 9 & Mendayung & $12-14$ & $16-18$ & $22-24$ \\
\hline 10 & Sepak Bola & $10-14$ & $11-13$ & $18-24$ \\
\hline 11 & Renang & $3-7$ & $10-12$ & $16-18$ \\
\hline 12 & Tenis & $6-8$ & $12-14$ & $22-25$ \\
\hline 13 & Bola Voli & $11-12$ & $14-15$ & $20-25$ \\
\hline 14 & Angkat Berat & $11-13$ & $15-16$ & $21-28$ \\
\hline 15 & Gulat & $13-14$ & $15-16$ & $24-28$ \\
\hline 16 & Bulu Tangkis & $8-9$ & $14-15$ & $18-24$ \\
\hline 17 & Hoki & $12-14$ & $16-18$ & $22-25$ \\
\hline 18 & Sofball & $10-12$ & $14-16$ & $18-24$ \\
\hline 19 & Panahan & $10-12$ & $17-18$ & $20-28$ \\
\hline 20 & Pencak Silat & $10-11$ & $15-16$ & $18-22$ \\
\hline 21 & Bola Tangan & $12-13$ & $15-16$ & $18-24$ \\
\hline 22 & Tenis Meja & $7-8$ & $10-12$ & $18-24$ \\
\hline 23 & Polo Air & $12-13$ & $15-16$ & $18-25$ \\
\hline 24 & Berkuda & $13-15$ & $17-18$ & $20-25$ \\
\hline 25 & Layar & $12-13$ & $15-16$ & $18-24$ \\
\hline 26 & Judo & $12-13$ & $15-16$ & $18-25$ \\
\hline 27 & Karate & $12-13$ & $15-16$ & $18-25$ \\
\hline & & & \\
\hline
\end{tabular}

Dari tabel diatas dapat dikatakan, bahwa usia untuk memulai latihan olahraga dalam batasan usia rata-rata disekolah dasar dan sedikit pada jenjang pendidkan SLTP, sedangkan usia terhadap pemilihan khusus terentang pada usia anak disekolah SLTP dan 
sedikit SLTA. Penampilan terbaik yang dapat diperlihatkan umumnya berada pada remaja sedikit pada usia mahasiswa dan terbanyak pada usia SLTA.

\section{PENUTUP}

Sekolah merupakan tempat diselenggaranya penyiapan sumberdaya manusia yang berkulaitas. Pendidikan jasmani sebagai salah satu mata ajar di sekolah disamping sebagai alat pendidikan dapat menghasilkan atlet berpotensi dalam menunjang prestasi olahraga nasional. Kepelatihan Olahraga, sebagai tenaga profesional, di samping tenaga pendidik pelaku progran kurikuler mampu mnyelenggarakan program ekstrakurikuler sebagai pelatih dan pembina olahraga.

\section{DAFTAR PUSTAKA}

Depdikbud. (1993). GBPP Pendidikan Jasmani. Departemen Pendidikan dan Kebudayaan Republik Indonesia.
Bompa, O Tudor. (1990) Theory and Methodology of Training. Dubuque: Kendall/Hunt Publishing Company.

Depdikbud. (1993). GBPP Pendidikan Jasmani. Departemen Pendidikan dan Kebudayaan Republik Indonesia.

Gabbard Carl. (1987). Psical Education For Children. New Jersy: Prentice Hall, Inc, Engelwood Cliffs.

Harsuki. (2003) Perkembangan Olahraga Terkini: Kajian Para Pakar. Jakarta : Raja Grafindo Persada. Ed. 1, Cet 1.

Harsono, (2016) Teori dan Metodologi Kepelatihan Olahraga. Bandung : PT. Remaja Rosdakarya.

Puskur Balitbang (2001), Kurikulum Berbasis Kompetensi, Kebijakan Umum Pendidikasan Dasar dan Menegah.

William Crain, (2017). Theories of Devlopment, Concepts and Applications. Printice hall, Englewood Cliffs, New Jersey. Edisi Bahasa Indonesia. Pustaka Pelajar. Yogyakarta. 